Макарова Т. М.

кандидат філологічних наук, дочент

\title{
ФОРМУВАННЯ ПАТРІОТИЧНОГО ЗАРОДКУ У СВІДОМОСТІ ДЖУРІВ-ХАРАКТЕРНИКІВ
}

У статті досліджується прочес формування патріотичних рис у свідомості дитини та ї̈ здатності до дорослих і відповідальних вчинків. Автор доводить, ио саме на таких, описаних у творі, зразках повинне виховуватись сучасне покоління.

Ключові слова: характерничтво, козачтво, свідомість дитини, Володимир Рутківський, «Джури козака Швайки», «Джури-характерники», «Джури $i$ підводний човен».

В статье исследуется прочесс формирования патриотических черт в сознании ребенка и его способность к взросльм и ответственным поступкам. Автор приходит к выводу, что именно на таких примерах и должно воспитываться современное поколение.

Ключевые слова: характерничтво, козачество, сознание ребенка, Владимир Рутковский.

The process of forming patriotic features in the child's mentality and the child's ability to domature and responsible acts have been studied in the article. The author has come to the conclusion that exactly the models of above-mentioned acts should be used for educating the modern generation.

Keywords: the "kharakternytstvo" - the Ukrainian Cossacks' system of esoteric and magical knowledge and practices; the Ukrainian Cossacks; the child's mentality; Vladimir Rutkovsky.

Нині особливо гостро постає потреба в розвитку дитячої літератури та ії активному поширенні серед різновікової читацької аудиторії, адаптованої до рівня сприйняття реципієнта. Однак це не повинно зменшувати вартість творів, адже кожна прочитана книжка - це вже джерело певної інформації. У наш час відбувається процес формування національної бази дитячої літератури, котра б незалежно від родо-жанрової динаміки захоплювала своїм тематичним розмаїттям, щирістю та багатогранністю вражень, доступністю 
сприйняття образів-персонажів і близькістю тематики й проблематики до сучасного читача. Адже саме відстороненість письменника від дитини та неврахування ії нових можливостей і сфер інтересів може призвести до остаточної втрати читацької аудиторії. На жаль, сьогодні мало хто може похвалитися знанням сучасних дитячих творів, що зумовлене як загальною втратою інтересу до книги, так і поширенням низьковартісних перевидань уже відомих зразків і масовим насадженням моделей європейської культури. Наші діти добре знають «суперменів», «людину-павука», «хеллбоя», захоплюються їхніми надможливостями та здібностями, оскільки сучасні засоби масової інформації надзвичайно прикрашають їх спецефектами й рекламують як зразки, на які варто орієнтуватися. А тому власні «супермени-характерники» залишаються осторонь, оцінені лише поодинокою аудиторією фахівців і справжніх поціновувачів дитячої літератури. Тож саме твори В. Рутківського покликані пом'якшити вищеназвані негативи реалій життя та повернути нас до власної минувшини із ії таємничими загадками й глибинними можливостями для творчої уяви письменників.

Окреслена проблема виявилася цікавою та дискусійною серед кола сучасних науковців. Зокрема Д. І. Яворницький у праці «Історія запорозьких козаків» особливу увагу приділив можливостям «характерників»: «відчиняти без ключів замки,вилазити з туго зав 'язаних, а також зашитих мішків, "перетворюватись" на котів, перевтілювати людей на кущіi» [Яворницький 1990: 236]. Л. Залізняк поглибив попередню думку семантичним наповненням імен відомих персонажів нашої історії та уособленням культу воїна, котрий символізує собою «мужність, силу, нещадність до ворогів» [Залізняк 1994: 162]. Схожість рис козаків-характерників 3 індоєвропейським культом воїна-звіра визначає Ю. Фігурний, а витоки цих вірувань, на його думку, сягають «епохи тотемізму» та мають давне історичне коріння, котре «украйнське козацтво прийняло у спадок від культури Київської Русі» [Фігурний 1999: 61]. Тарас Каляндрук пов'язує характерників із «кастою українських 
воїнів», які своїми здібностями «несли надзвичайно велику відповідальність, адже воїн, володіючи військовим знанням і маючи в руках зброю, міг використати ї̈ як на добро, так і на зло» [Каляндрук 2007: 192].

Не обійшли увагою дослідники як саму творчість письменника (В. Василашко [Василашко 2008], О. Гаврош [Гаврош 2008], 3. Жук [Жук 2007]), так і їі можливості в процесі розвитку дитячої літератури (К. Родик [Родик], Т. Щербаченко [Щербаченко] та ін.), наголошуючи, що «він вивірив "історію" $i$ "метод" $i$ впродовж кропіткої роботи над дитячою історичною трилогією не зійшов зі иляху епічного екшену на сумнівну стежку поверхового слайдшоу» [Щербаченко: 1] та створив «компенсачійну літературу для усіх тих, хто захоплюється Брюсом Віллісом, Сильвестром Сталлоне» [Родик: 2].

Саме така полярність вивчення творчості В. Рутківського свідчить про різноаспектність проблем, котрі можуть зацікавити дослідників. Усе це переконує, що питання формування найкращих зразків у літературі для дітей вимагає як системності в процесі літературознавчих досліджень, так і особливої уваги з боку читачів різного віку.

Завдання статті-простежити за процесом формування патріотичних рис у свідомості джурів-характерників і їхньої здатності до дорослих, відповідальних вчинків (на прикладі трилогії В. Рутківського «Джури козака Швайки», «Джури-характерники», «Джури і підводний човен»).

Цікавими, й до нині непізнаними, $є$ більшість сторінок нашої історії, так само як і оцінка позицій учасників. У цьому й простежується ії схожість із процесом формування та розвитку дитини, яка під час первинної соціалізації виявляє багато такого пізнавального та неповторного, що залишається поза увагою найближчого оточення. I тільки найдопитливішому читачеві вдається перетнути межу цієї загадковості й адаптувати ії до сучасних реалій. Прикладом цього є життєві долі маленьких хлопчаків із селища Воронівка - 
Грицика та Санька й відважного козака Швайки, який став для них зразком для наслідування.

У ті часи, коли Україна потерпала від нападу татаро-монгольської орди, серед населення знаходилося багато добровольців, котрі відправлялися на Січ, щоб навчатися вправності в бойових мистецтвах і захищати рідну землю від ворогів. Особливою повагою серед них користувався козак-вивідник Пилип, якого за сміливість та нездоланність у боротьбі Гафур-ага назвав Швайкою - «мовляв, итрикає ординців, мов швайка» [Рутківський 2007: 10]. Особливе ставлення до ворогів викарбувалася в його свідомості неспроста, адже не оминула татарська навала болем і родину цього козака. На власні очі хлопчик бачив, як спалили живцем його батька, залишивши Пилипа сиротою, і з тих пір його домівкою став «увесь білий світ від Канева до Кафи, від Переяслава до Хаджибея...» [Рутківський 2007: 44]. Саме це, глибоко закорінене у свідомості дитини відчуття ненависті до ворогів його краю й породило активне прагнення захищати людей, шліфувати власну майстерність боротьби та вміння відчувати природу і їі можливості. I в результаті одна тільки згадка його імені для пана Кобильського, Менглі-Гірея, Колотнечі, Тишкевича, Богдана Глинського й інших викликала острах і порівнювалася із «виляском батога», бо й було чого остерігатися: «невловимий, як вовк, і всюдисущий, як лис, він може довідатись навіть про те, щуо й на ханській раді пошепки мовиться. А що вже товарии за друга власне життя віддасть $і$ не скривиться» [Рутківський 2010: 7], - свідчить одна з інохарактеристик непереможного героя.

Та найціннішим у творі $\epsilon$ те, що устами Швайки автор роману вчить не сіяти по всьому світові злість і не ставитися до людей вороже, бо й серед ворогів (татар) «теж є люди» [Рутківський 2007: 216]. Яскравим прикладом цього є постать Рашита, мати якого врятувала Пилипа від смерті, взявши його на виховання до себе після розправи татар над матір'ю Швайки.

Не залишаються поза увагою читача й ще поки що маленькі паростки великого майбутнього - воронівські хлопці: Санько, котрий 
«уміс подумки віддавати накази й прохання» [Рутківський 2007: 14], і його друг Грицик. Особливо гострим для хлопчаків було бажання козакувати, та боялися матері за своїх синів, адже пам'ятали вони про постраждалих у Михайлівці. 3 тривогою до бажання сина ставилася й мати Санька, чого не відчував ніколи Грицик, адже «ще з позаминулої осені, коли зненацька наскочили татаpu...» [Рутківський 2007: 21], зостався він сиротою на цьому світі. Змалку хлопчик відзначався здатністю розвідувати, особливо захоплювало його бажання розгадати загадку вовкулацького кута, де, на його думку, вирувала нечиста.

Найперший кмітливий вчинок друзів, який запам'ятається надовго односельчанам і знайде відголосок серед відважних козаків, це перешкоджання плану пана Кобильського (вони навмисне на весь голос закричали «тікайте! Татари йдуть!» [Рутківський 2007: 57]), котрий задля укріплення власної охорони вирішив силоміць забрати з родин молодих хлопчаків, які не встигли відправитися на козакування. Та не знали Санько і Грицик, що така дитяча витівкапорятунок надто дорого буде коштувати їхнім односельцям, бо не прощає пан посміх і супротив його діям. Саме ця пригода й змусила друзів залишити рідні домівки задля власного порятунку.

Другим випробуванням на міцність виявилася боротьба 3 дикою кішкою, у якій дитячій упевненості довелося поступитися страху, і якби не чаклування Санька, котрий подумки «уявив, як дика кішка, зупинившись, почала роздумувати, щя їй робити далі. Потім вона розвернулася і поволеньки стала спускатися по стовбуру...» [Рутківський 2007: 72], невідомо чим би й закінчилася історія юних сміливців. Та великою проблемою для маленького чародія було невміння контролювати свої здібності, хоча й відчував хлопець, що багато сил витратив на цей мисленнєвий двобій. А всі подальші, непідвладні дитячому осмисленню, події (поява 3 Грицикового сховку луків і сагайдака зі стрілами; розмови про вовкулаків; переслідування вовка) викликали невтомне шукання порятунку поблизу Кам'яного острова. 
Так, відірвавшись від перешкод і мандруючи світом, друзі не переставали мріяти про власне майбутнє, про подвиги, якими б гордилися їхні земляки. А на пам'ять щоразу приходив козак Швайка, котрий у розповідях дідів поставав найсильнішим та непереможним, і саме на нього хотілося бути схожим Грицикові: «щоб мене татари боялися» [Рутківський 2007: 152].

Одного разу хлопцям довелося бути свідками гонитви татар за надзвичайно спритним наїзником, який на довгий час немов розчинився в дніпровських плавнях, а згодом заговорив до них із верби людським голосом. Як виявилося пізніше, це й був Швайка, знайомство з яким відкрило нову сторінку в житті Саньки і Грицика козакування. Та якось по-особливому відбилася у свідомості ватажка зустріч із дітьми: Грицик захоплював його своєю дитячою сміливістю, а в Санькові було щось таке, «що не вкладається у розум звичайної людини» [Рутківський 2007: 142]. I саме допомога хлопчаків у погоні за Тишкевичем і порятунок у вовчому лігві («Поглянь у бік... обійди навколо... - пошепки умовляв Сашко. Щось ніби підказувало йому, що з иим степняком треба балакати так, як свого часу він балакав з дикою кішкою-риссю, а пізніше з Барвінком» [Рутківський 2007: 192]) від татарського полону остаточно сприяли розгадці незрозумілої йому загадки: цей хлопчина - майбутній волхв.

Тож саме такими сміливими вчинками й упертими діями друзі переконували козаків і самого Швайку в тому, що на них варто покладатися, а їхня дитячість - це лише питання часу. Та й іронічне зауваження Вирвизуба про вік та спритність малечі не стало на перешкоді рішенню вивідника, а натомість - ще більше викликало повагу козацької братії до тих, за кого міг поручитися їхній товариш. I в результаті, перша й найвища нагорода - воронівські хлопчаки стали джурами Пилипа.

Наступним переломним етапом у житті Грицика й Санька стала зустріч із дідом Кудьмою, яка в першого викликала не тільки ревнощі («Санько, який і мухи не скривдить - і раптом страшний волхв!) [Рутківський 2007: 213]), а й страх втратити друга, оскільки 
він знав, що люди з такими здібностями живуть у недосяжних для людського ока місцях, а відповідно, не мають ні близьких, ні знайомих. А щодо другого, то час перебування в наймудрішого волхва, котрий навчив його «сили від неба набирати, $i$ на ворожінні всілякому почав тямити, і лікувати накладанням рук теж уміє. I в травах непогано кумекає» [Рутківський 2007: 287], виявився особливим. Саме тут хлопчик усвідомив найважливішу у своєму житті істину - власні сили варто спрямовувати тільки на добро й нести відповідальність за визначену обраність: «Краще помізкуй, як те, що в тебе Богом закладено, віддати добрим людям. Бо так лише даремно сили тратиш...» [Рутківський 2007: 288], - наголошував дід Кудьма. Однак, мабуть, через вікову недалекоглядність і Санькові, і Грицикові важко було усвідомити важливість власного призначення («Санько з заздрістю подивився на свого товариша. Гарно йому живеться: є кінь, Швайка поруч, їдь куди заманеться... А Грицик із заздрістю дивився на Санька. Щастить же людині! Поруч з дідом Кудьмою бути - таке не кожному дано. 3 його знайомих лише Швайка жив біля діда. Навіть Вирвизуб не удостоївся такої честі» [Рутківський 2007: 320]), котрого вимагатиме від них майбутнє. Та знову ж таки на заваді ставали жаль і певне розчарування щодо нездійснених мрій.

За п'ять років свого мандрування хлопці багато в чому проявили себе: відбили напад Саїдової орди, вивчили татарську мову, шліфували основи «ворожбицьких таємнищь» і «вміння слухати світ» [Рутківський 2009: 32]. У нагоді видався й дар Санькахарактерника: завдяки здатності мандрувати майбутнім було врятовано маленьких татарчат, а перевтілювання на певний час у ворога й маніпулювання його свідомістю сприяли розкриттю намірів ворога очистити всі плавні від козаків, бо «такого волхва ще треба вдень з вогнем пошукати $\square . . \square$ Йому нічого не варто відвести очі татарам чи побачити, що буде завтра. I звірі його слухають. Надто вовки» [Рутківський 2010: 30]. Така позиція хлопців ще раз засвідчує прагнення застосовувати всі можливості 
заради порятунку земляків і тих, хто страждає від зловісних намірів загарбників або виявився їхнім заручником. Та при цьому самовільно не чинити зла.

Найскладнішим випробуванням для всіх козаків стала реалізація задуму Швайки-Карачобана: підняти повстання невільників у Кафі проти татар. Саме тут неочікуваними виявилися дві події: зміна планів Іслам-Гірея щодо майбутнього невільників і зустріч із Зарембою, який у передчутті власної смерті зрадив своєму народові й виказав невловимого вивідника. I тепер настала черга джурів віддячити Швайці за минуле. Та отримана перемога не тільки схвилювала вивідника, а й докорінно змінила позиції хлопців, бо саме в цей час Швайка відчув, що підготував собі гарну заміну «винахідливого не по літах» [Рутківський 2009: 116] Грицика. А штурм очаківської фортеці, захоплення турецької галери та порятунок із полону друзів Грицика - Хасана й Рената засвідчили, що таким відчайдушним джурам «і десяток нападників не страшний» [Рутківський 2009: 227]. Тобто вірність і відданість юнаків стали їхніми найвищими чеснотами. А приклад їхньої сміливості та самостійності під час прийняття рішень можна розглядати як реалізацію складного процесу формування патріотичного зародку у свідомості джурі-характерників.

Наполегливо працював над собою й Санька. Так, підчас порятунку Грицика йому вдалося не тільки подолати в собі жалість до близької людини, а ще й перевершити власних учителів - «зробити з Грищика справжнього характерника! Розумісш - справжнього! Вперше за стільки років! Ні дідові Кудьмі, ні дідові Куделі чього не вдавалося!» [Рутківський 2010: 285]. А все це завдяки відомому йому методу: «вивести $\square \ldots \square$ niд спечене сонще, дати нагрітися голові, а тоді вилити на неї відро крижаної води» [Рутківський 2010: 275], і в результаті такої стресової ситуації людина здатна відкрити в собі надзвичайні властивості. Саме цей експеримент міг у майбутньому послужити відродженню характерництва серед усіх вірних козаків і набути статусу непереможних. 
Отже, твори В. Рутківського не тільки ілюструють маловідомі сторінки історії України, а щей дозволяють як читачеві, так і досліднику об'єктивно осмислити й оцінити наміри маленьких героїв та процес формування їхніх життєвих позицій. Дії та вчинки Швайки, Грицика, Санька виступають яскравим прикладом винахідливості, відповідальності, вправності, стійкості в досягненні мети й здатності бути надійною опорою як для своїх родин, так і для рідної землі. Не по-дитячому дорослі вчинки й успішні дії стають прикладом для сучасних юнаків, котрі знаходяться ще в процесі пошуку гідних зразків для наслідування. Та найголовнішим $є$ те, що сам автор устами маленьких героїв учить спрямовувати свої сили на добро, допомагати людям і вміти розгледіти й серед ворогуючого населення добрих людей (Рашит, Хасан, Ренат). Адже тільки так ми зможемо не втратити людське обличчя, примусити ворогів поважати наш народ. Подальшого дослідження потребує вивчення історичних фактів у творчості письменника та процес формування характеру дитини.

\section{БІБЛІОГРАФІЯ}

Василашко 2008 - Василашко В. Ластівка п’є на льоту : про історичний роман «Джури козака Швайки» / В. Василашко // Літературна Україна, 2008. 7 лют. - С. 6.

Гаврош 2007 - Гаврош О. Джура української літератури : В. Рутківський наверстує час - виходять дві нові кн. дит. письм. з Одеси [«Джури козака Швайки», «Потерчата»] / О. Гаврош // Україна молода, 2008. - 5 листоп. - С. 10.

Жук 2007 - Жук 3. «Дзвін шабель, пісні, походи...» : про історичний роман В. Рутківського «Джури козака Швайки» / 3. Жук // Друг читача, 2007. - № 13. - С. 3.

Залізняк 1994 - Залізняк Л. Л. Нариси стародавньої історії України /

Л. Л. Залізняк. - К. : Абрис, 1994. - 254 с.

Каляндрук 2007 - Каляндрук Т. Загадки козацьких характерників / Т. Каляндрук. Львів : ЛА «Піраміда», 2007. - 288 с.

Родик - Родик К. Український Жуль Верн [Електронний ресурс] : [Володимир Рутківський відновив традищії українського екшену] / К. Родик. - Режим доступу : http://bukvoid.com.ua/digest/2011/02/15/122252.html.

Рутківський 2007 - Рутківський В. Джури козака Швайки / В. Рутківський // Історична трилогія для дітей. - Кн. 1. - К. : А-БА-БА-ГА-ЛА-МА-ГА, 2007. - 432 с.

Рутківський 2009 - Рутківський В. Джури-характерники / В. Рутківський // Роман. 2-га книга трилогії «Джури». - К. : А-БА-БА-ГА-ЛА-МА-ГА, 2009. - 448 с. Рутківський 2010 - Рутківський В. Джури і підводний човен / В. Рутківський // Роман. Заключна книга трилогії «Джури». - К. : А-БА-БА-ГА-ЛА-МА-ГА, 2010. - 400 с. 
Фігурний 1999 - Фігурний Ю. Образ козака-характерника як відгомін індоєвропейського культу воїна-звіра / Ю. Фігурний // Пам'ять століть, 1999. - № 4. - С. 57-61.

Щербаченко - Щербаченко Т. У Гаррі Поттера з'явилися «конкуренти» в Україні. Джури та мури дитячого письменника Володимира Рутківського [Електронний ресурс]. - Режим доступу: http://dt.ua/CULTURE/u_garri_pottera

zyavilisya_konkurenti_v_ukrayini_dzhuri_ta_muri_dityachogo_pismennika_volodi mira_r-73706.html.

Яворницький 1990 - Яворницький Д. I. Історія запорозьких козаків /

Д. І. Яворницький // Твори : у 3 т. - Т. 1. - К. : Наукова думка, 1990. -450 с. 